\title{
Influences of Barks Addition on the Growth of Microorganisms and the Ingredients of Basi in Basi Fermentation
}

\author{
Mura Kiyoshi*1, Sanchez Priscilla C. ${ }^{* 2}$ and TAnimura Wahachiro*1 \\ * 1 Faculty of Applied Bioscience, Tokyo University of Agriculture \\ 1-1-1, Sakuragaoka, Setagaya-ku, Tokyo 156-8502, Japan \\ * 2 Institute of Food Science and Technology, University of the Philippines at Los Baños \\ College, Laguna 4031, Philippines
}

\begin{abstract}
Using a mixture of samac bark and fruit in equal quantity (SBF), which is used in the sugarcane wine- "basi" brewing in the Pangasinan of Philippines, we have prepared basi with and without the addition of barks, and have studied the impact of barks addition on the growth of microorganisms and the ingredients of basi. No impact of SBF addition was seen on the growth of yeasts like Saccharomyces cerevisiae, and no difference was found in the alcohol yields between basi with and without SBF addition. The growth of lactic acid bacteria was completely inhibited by SBF, indicating that the growth of lactic acid bacteria - the cause of souring - can be suppressed by the addition of barks in basi fermentation. Besides, the basi after fermentation with the addition of SBF had a strong astringency resulted from the polyphenol components dissolved from SBF. Though basi with SBF addition had a sugar concentration as high as $11.2 \%$, as its sweetness had been moderated by the astringency of polyphenol, it had a mild taste, showing an important significance of barks addition to confer astringency in basi fermentation.
\end{abstract}

(Received Aug. 31, 2001 ; Accepted Jan. 27, 2003)

There is a sugarcane wine called "basi" in the northwest of Luzon in the Philippines from old times $^{1)}$. Basi is a fermented liquor and has a strong sweetness and astringency. The preparation method of basi is handed down from generation to generation among the people and some barks are added to the sugarcane juice before fermentation. Usually, the barks used in basi preparation are bark, fruit and leaf of samac (Macharanga grandifolia Linn.) and bark of duhat (Sizygium cumini Skeels).

We have previously investigated the influence of various aqueous extracts of barks added to basi on the growths of lactic acid bacteria, acetic acid bacteria and yeasts, and have found that most of the aqueous extracts intensely inhibit the growths of lactic acid bacteria and acetic acid bacteria, which are the cause of souring during basi fermentation, suggesting that barks addition brings about an opportune control of microorganisms in basi fermentation ${ }^{2)}$. Moreover, we have studied substances inhibiting the growth of lactic acid bacteria in the barks added to basi and have identified that, the major inhibitory substance is a high molecular weight condensed tannin consisting of catechin and leucoanthocyanin in samac bark, a gallotannin with multiple galloyl radicals and $\mathrm{m}$ digalloyl radicals bound to the glucose or xylose of sugar in samac fruit, and a high molecular weight condensed tannin consisting of gallic acid and leucoanthocyanin in duhat $\operatorname{bark}^{3) \sim 6)}$.

In this study, together with the elucidation on basi ingredients by analyzing the basi produced in the Philippines, we have performed the fermentation of basi with and without the addition of barks, compared the transition of microorganisms and the change of ingredients during the fermentation, and investigated the impact of barks addition on the growth of microorganisms and the ingredients of basi.

\section{Materials and Methods}

\section{Materials}

Basi produced in the La Union of Philippines were used as materials to analyze the ingredients.

* 1 E-mail : MurA Kiyoshi ; mura@nodai.ac.jp

* 2 E-mail : psanchez@laguna.net 


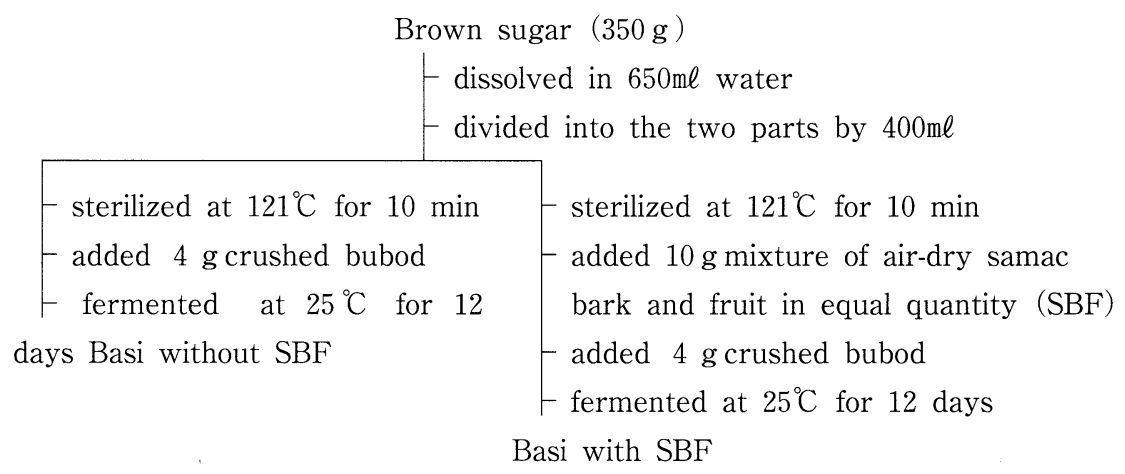

Fig. 1 Procedures for the fermentation of basi

The bubod made in the La Union was used as starter in basi fermentation, and air-dry samac bark and fruit used in the Pangasinan ${ }^{11}$ were used as barks to add to basi.

\section{Basi fermentation}

The fermentation of basi with and without the addition of barks was carried out according to the procedures shown in Fig. 1. To 650m water, $350 \mathrm{~g}$ brown sugar was added and dissolved by heating, then the solution was divided into $400 \mathrm{~m} \ell$ each in two Erlenmeyer flasks of $1,000 \mathrm{~m} \ell$ volume and sterilized at $120^{\circ} \mathrm{C}$ for $10 \mathrm{~min}$. After sterilization, to one flask $4 \mathrm{~g}$ crushed bubod alone was added and to the other both $4 \mathrm{~g}$ crushed bubod and $10 \mathrm{~g}$ mixture of samac bark and fruit in equal quantity (SBF) were added, and both were fermented at 25 ${ }^{\circ} \mathrm{C}$ for 12 days.

\section{3 . Ingredient analysis}

Alcohol was determined by hydrometer method $^{7)}$, total sugar by Somogyi-Nelson method ${ }^{8)}$ after hydrolysis of sucrose, total acid by alkaline titration $\operatorname{method}^{9)}$, and polyphenol by Folin-Denis method ${ }^{10)}$. The hydrolysis of sucrose was carried out at $65^{\circ} \mathrm{C}$ for $15 \mathrm{~min}$ after adding $5 \mathrm{~m} \ell$ of $25 \% \mathrm{HCl}$ to $50 \mathrm{~m} \ell$ of material solution. Total sugar was calculated as glucose, total acid as succinic acid, and polyphenol as $\mathrm{D}$ - $(+)$-catechin.

Organic acids were determined individually using an automatic carboxylic acid analyzer $(\mathrm{S}-500$; Seishin Pharmacy, Ltd., Tokyo). Protein has to be removed beforehand from the material solution for the automatic carboxylic acid analyzer and this was done by adding $2 \mathrm{~m} \ell \quad 10 \% \mathrm{HClO}_{4}$ to $8 \mathrm{~m} \ell$ of the material solution, refrigerating overnight, and removing the protein precipitate by centrifugation ${ }^{11}$.

\section{Measurement of viable cell count}

Viable cell count was measured by plate culture method $^{12)}$. Yeasts and molds were cultured on YM agar media (yeast extract $0.3 \%$, malt extract $0.3 \%$, peptone $0.5 \%$, glucose $1.0 \%$, agar $1.5 \%, \mathrm{pH} 5.8$ ) at $28^{\circ} \mathrm{C}$ for 23 days, and their viable cell counts were calculated respectively. For yeasts, those with filamentous rim in a colony were calculated as $\mathrm{R}$ yeast and others as $\mathrm{S}$ yeast. Lactic acid bacteria were cultured on GYP agar media containing $\mathrm{CaCO}_{3}$ (glucose $1.0 \%$, yeast extract $0.5 \%$, peptone $0.5 \%$, $\mathrm{CaCO}_{3} 0.5 \%$, agar $\left.1.5 \%, \mathrm{pH} 6.8\right)$ at $37^{\circ} \mathrm{C}$ for 23 days and the viable cell count was calculated as colonies with a clear zone due to the elution of $\mathrm{CaCO}_{3}$ from the media.

\section{Results}

\section{Basi ingredients}

The ingredients of basi produced in the Philippines wine were shown in Table 1 and compared with them of red wine ${ }^{13)}$ which contains polyphenol of grape seeds. The alcohol content of basi was similar to that of the red wine. The total sugar content of basi was as high as that of

Edufuaule wine having high sugar content. The

Table 1 Comparison of ingredients between basi and red wine

\begin{tabular}{lccccc}
\hline Wine & $\begin{array}{c}\text { Alcohol } \\
(\mathrm{m} \ell / 100 \mathrm{~m} \ell)\end{array}$ & $\begin{array}{c}\text { Total sugar } \\
(\mathrm{g} / 100 \mathrm{~m} \ell)\end{array}$ & $\begin{array}{c}\text { Total acid } \\
(\mathrm{mg} / 100 \mathrm{~m} \ell)\end{array}$ & $\begin{array}{c}\text { Polyphenol } \\
(\mathrm{mg} / 100 \mathrm{~m} \ell)\end{array}$ & $\mathrm{pH}$ \\
\hline Basi & 12.5 & 12.20 & 283 & 285 & 4.21 \\
Red wine* & 11.8 & 0.15 & 620 & 132 & 3.50 \\
\hline
\end{tabular}

*These values were quoted from 'Constituents in Fermented Foods' (1999) ${ }^{13)}$ 
Table 2 Viable cell counts in bubod

\begin{tabular}{lc}
\hline Microorganism & $\begin{array}{c}\text { Viable cell count } \\
(\mathrm{CFU} / \mathrm{g})\end{array}$ \\
\hline Mold & $7.0 \times 10^{5}$ \\
Yeast & \\
R yeast* & $3.8 \times 10^{8}$ \\
$\quad$ S yeast** & $6.6 \times 10^{7}$ \\
Lactic acid bacteria & $8.3 \times 10^{5}$ \\
\hline
\end{tabular}

* Colonies with filamentous rim were counted as $\mathrm{R}$ yeast. **Colonies with smooth surface were counted as $\mathrm{S}$ yeast.

total acid content of basi was lower than that of the red wine. The polyphenol content of basi was higher than that of the red wine and the sweetness of sugar was moderated by the strong astringency of polyphenol.

\section{Influence of SBF addition on the growth of microorganisms in basi fermentation}

The microorganisms included in the bubod used as a starter in basi fermentation were yeasts, molds and lactic acid bacteria, as shown in Table 2. In the bubod, the number of yeasts with filamentous rim in a colony ( $\mathrm{R}$ yeasts) were $3.8 \times 10^{8} \mathrm{CFU} / \mathrm{g}$ and the number of other yeasts (S yeasts) were $6.6 \times 10^{7} \mathrm{CFU}$ $\angle \mathrm{g}$. The main $\mathrm{R}$ yeast was identified Sacchromycopsis fibuligera and the main S yeast was identified Saccharomyces cerevisiae. And the main mold was Rhizopus and the main lactic acid

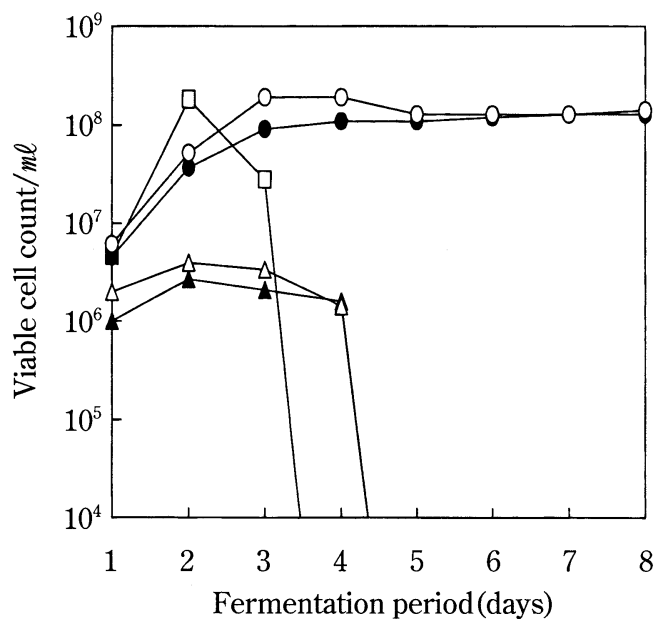

Fig. 2 Changes of the viable cell counts of yeasts and lactic acid bacteria during the fermentation of basi with and without the addition of samac bark and fruit

The fermentation of basi was carried out according to the procedures shown in Fig. 1.

$\mathrm{O}: \mathrm{S}$ yeasts in basi without $\mathrm{SBF}$,

$\mathrm{S}$ yeasts in basi with $\mathrm{SBF}$

$\triangle: \mathrm{R}$ yeasts in basi without $\mathrm{SBF}, \boldsymbol{\Delta}: \mathrm{R}$ yeasts in basi with $\mathrm{SBF}$,

$\square$ : lactic acid bacteria in basi without SBF. bacterium was Pediococcus ${ }^{14), 15)}$

Using the bubod as a starter, we have carried out fermentation of basi with and without SBF addition, and have compared the transition of microorganisms in both during the fermentation process. The results were showed in Fig. 2. No significant difference in the growth of $\mathrm{S}$ yeasts with $S$. cerevisiae was seen between basi with SBF and that without $\mathrm{SBF}$, regardless of a slight growth inhibition in the early stage of fermentation in basi with SBF. Nearly no growth of $\mathrm{R}$ yeasts with $S$. fibuligera was seen in either basi with SBF or that without SBF, and all died out on the 4th day of fermentation when the growth of $\mathrm{S}$ yeasts became significant. In lactic acid bacteria, significant growth was seen in the early stage of fermentation in basi without SBF, while no growth at all was observed

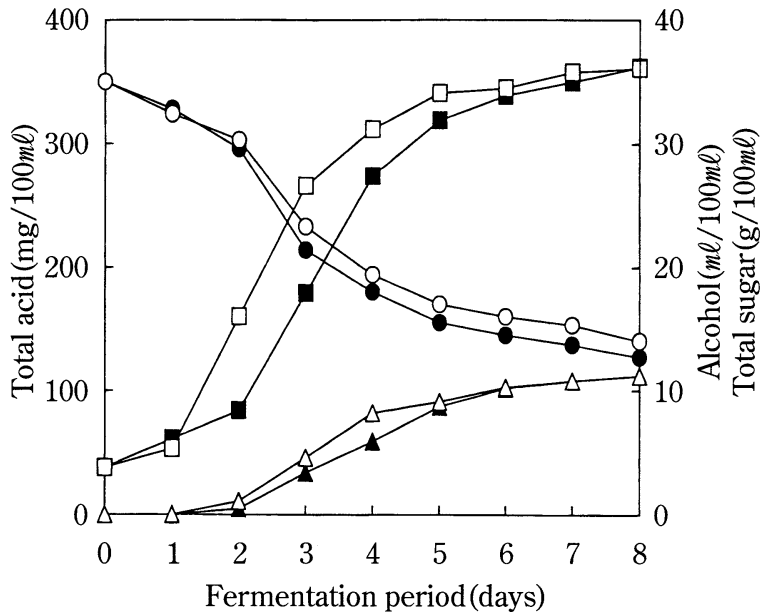

Fig. 3 Changes of the ingredients during the fermentation of basi with and without the addition of samac bark and fruit

The fermentation of basi was carried out according to the procedures shown in Fig. 1.

$\bigcirc$ : total sugar in basi without SBF, 0 : otal sugar in basi with $\mathrm{SBF}, \triangle$ : alcohol in basi without $\mathrm{SBF}, \boldsymbol{\Delta}$ : alcohol in basi with $\mathrm{SBF}$, $\square$ : total acid in basi without SBF, $\square$ : total acid in basi with SBF. 
Table 3 Ingredients of basi with and without the addition of samac bark and fruit

\begin{tabular}{lccccc}
\hline \multicolumn{1}{c}{ Basi } & $\begin{array}{c}\text { Alcohol } \\
(\mathrm{m} \ell / 100 \mathrm{~m} \ell)\end{array}$ & $\begin{array}{c}\text { Total sugar } \\
(\mathrm{g} / 100 \mathrm{~m} \ell)\end{array}$ & $\begin{array}{c}\text { Total acid } \\
(\mathrm{mg} / 100 \mathrm{~m} \ell)\end{array}$ & $\begin{array}{c}\text { Polyphenol } \\
(\mathrm{mg} / 100 \mathrm{~m} \ell)\end{array}$ & $\mathrm{pH}$ \\
\hline Without SBF & 12.3 & 13.5 & 385 & 28 & 3.90 \\
With SBF & 12.7 & 11.2 & 388 & 144 & 4.02 \\
\hline
\end{tabular}

The fermentation of basi was carried out according to the procedures shown in Fig. 1.

Table 4 Organic acids in basi with and without the addition of samac bark and fruit $(\mathrm{mg} / 100 \mathrm{~m} \ell)$

\begin{tabular}{lcc}
\hline \multirow{2}{*}{ Organic acid } & \multicolumn{2}{c}{ Basi } \\
\cline { 2 - 3 } & Without SBF & With SBF \\
\hline Formic acid & 7.6 & 8.1 \\
Acetic acid & 135.2 & 180.1 \\
Succinic acid & 76.0 & 79.0 \\
Lactic acid & 150.8 & 57.4 \\
Malic acid & 13.9 & 40.5 \\
Citric acid & 18.0 & 22.9 \\
Pyruvic acid & 18.9 & 27.7 \\
$\alpha$-Ketoglutaric acid & 7.5 & 4.5 \\
\hline
\end{tabular}

The fermentation of basi was carried out according to the procedures shown in Fig. 1.

in basi with $\mathrm{SBF}$. This result indicated that the growth of lactic acid bacteria was completely inhibited by the addition of SBF. On the other hand, no growth of molds was found in either basi with or without SBF.

\section{Influence of SBF addition on the basi ingredients in basi fermentation}

The change of ingredients during fermentation process had been compared between basi with and without SBF, and the result was shown in Fig. 3. The production of alcohol was late in basi with SBF in the early days and this is consistent with the result that the growth of $\mathrm{S}$ yeasts is late in this basi compared to that without SBF. Nevertheless, no difference was seen in the alcohol yield between two types of basi from the 6th day of fermentation. Similarly, the production of acids was also late in basi with SBF in the early days, but the acid yield was the same in two types of basi from the 8th day of fermentation.

Table 3 showed the result of the comparison of ingredients in two types of basi after 12 days of fermentation. The alcohol content was $12.3 \mathrm{~m} \ell / 100 \mathrm{~m} \ell$ in basi without SBF and $12.7 \mathrm{~m} \ell / 100 \mathrm{~m} \ell$ in basi with $\mathrm{SBF}$, being a little higher in the latter. Polyphenol was the ingredient having significantly different contents between basi with SBF and that without $\mathrm{SBF}$; its content was $28 \mathrm{mg} / 100 \mathrm{~m} \ell$ in basi without $\mathrm{SBF}$ and $144 \mathrm{mg} / 100 \mathrm{~m} \ell$, about 5 -fold higher in basi with SBF. In addition, organic acids have been compared on the 12th day of fermentation and the result was shown in Table 4. There was no difference in the total acid content between the two types of basi, but difference was seen in individual organic acid. In basi without SBF, lactic acid and acetic acid were numerous. In basi with SBF, acetic acid was numerous but lactic acid was less.

\section{Discussion}

The preparation method of basi is different from area to area $^{1)}$. In some areas, starter is used for fermentation while in other areas, fermentation is performed naturally without starter. In areas where starter is used, bubod is usually used as a starter. Bubod is made according to the following process: To some smashed rice and ginger, water is added and the mixture is kneaded; next some crushed old bubod is added and the mixture is made into a disc; then the disc is left indoors for several days to let microorganisms grow and is finally air-dried completely in the open. In the Philippines, bubod is used as a starter mainly in tapuy, a rice wine ${ }^{16)}$. In this study, using the bubod as a starter, we have carried out fermentation of basi with and without the addition of SBF, and have compared the transition of microorganisms and the change of ingredients in the two basi. In the fermentation of basi with $\mathrm{SBF}$, SBF was added in $2.5 \%$ to the 
sugar solution based on the preparation method in the Pangasinan.

In both basi with SBF and that without SBF, significant growth of $\mathrm{S}$ yeasts with $S$. cerevisiae which performs alcohol fermentation being the majority is seen from the beginning of fermentation, and no influence of SBF addition is found on the growth of $\mathrm{S}$ yeasts. $\mathrm{R}$ yeasts with $S$. fibuligera being the majority die out from the 4 th day of fermentation when the growth of $\mathrm{S}$ yeasts becomes significantly in both basi with and without SBF, and this is thought to be resulted from the alcohol produced by $S$. cerevisiae. In contrast to the significant growth in the early stage of fermentation in basi without SBF, the growth of lactic acid bacteria is not seen at all in basi with SBF, showing a complete inhibition of growth of lactic acid bacteria by SBF addition. In the previous paper $^{2}$, we have reported that most of the aqueous extracts of barks added to basi inhibit the growth of lactic acid bacteria. In this study, we have confirmed that the growth of lactic acid bacteriathe cause of souring - is inhibited by the addition of barks in basi fermentation. Besides, Nishiyama, et al ${ }^{17)}$ reported that souring to occur by acetic acid bacteria and lactic acid bacteria is prevented by the addition of mangrove bark in the fermentation of tuba, a nipa sap wine in Philippines.

In basi with $\mathrm{SBF}$, the growth of $\mathrm{S}$ yeasts is a little late and as a result the production of alcohol is also slightly late but on the 12 th day of fermentation, no difference in the alcohol yield is found between basi with SBF and that without SBF. On the 12th day of fermentation, the total acid contents are the same in the two basi, but the lactic acid contents are greatly different, being $150.8 \mathrm{mg} / 100 \mathrm{~m} \ell$ in basi without SBF and $57.4 \mathrm{mg} /$ $100 \mathrm{~m} \ell$ in basi with SBF. Since no growth of lactic acid bacteria is found in basi with SBF, the low lactic acid content in this basi is thought to be due to the lack of growth of lactic acid bacteria. However, basi with SBF includes lots of acetic acid and the total acid content is the same as that of basi without SBF. This result suggests that acid production of yeasts is encouraged by addition of $\mathrm{SBF}$. Besides, in basi with $\mathrm{SBF}$, the polyphenol content reaches to $144 \mathrm{mg} / 100 \mathrm{~m} \ell$ on the 12 th day of fermentation, resulting in a strong astringency in the basi. In basi without SBF, the sugar content is $13.5 \mathrm{~g} / 100 \mathrm{~m} \ell$ on the 12 th day of fermentation and the sweetness is too strong to drink as an alcoholic beverage. Whereas in basi with SBF, regardless of its $11.2 \mathrm{~g} / 100 \mathrm{~m} \ell$ sugar, it has a mild taste since its sweetness has been moderated by the strong astringency of polyphenol. Therefore the conferring of astringency by adding barks is an important significance for basi and that is similar to the conferring of astringency on red wine by adding grape seeds.

\section{References}

$1)$ Tanimura, W., Sanchez, P. C. and Kozaki, M. : The fermented food in the Philippines. (Part 2) Basi (Sugarcane wine), J. Agric. Sci., Tokyo Nogyo Daigaku, 22, 135 (1977)

2 ) Mura, K. and Tanimura, W.: Influence of samac bark, samac fruit, samac leaf, and duhat bark on growth of microorganisms, Hakkokogaku Kaishi, 64, 1 (1986)

3 ) Mura, K., Iitoi, Y. and Tanimura, W. : Growth inhibition of lactic acid bacteria by samac (Macharanga grandifolia Linn.) bark, Hakkokogaku Kaishi, 64, 417 (1986)

4) Mura, K., Iitoi, Y. and TAnimura, W. : Inhibitory substance for the growth of lactic acid bacteria in samac (Macharanga grandifolia Linn.) bark, Hakkokogaku Kaishi, 65, 399 (1987)

5 ) Mura, K., Shiramatsu, H. and Tanimura, W. : Inhibitory substance for the growth of lactic acid bacteria in samac (Macharanga grandifolia Linn.) fruit, Nippon Shokuhin Kagaku Kogaku Kaishi, 43, 866 (1996)

6 ) Mura, K., Shiramatsu, H. and Tanimura, W. : A substance inhibiting the growth of lactic acid bacteria in duhat (Sizygium cumini Skeels) bark, Biocontrol Science, 5, 33 (2000)

7 ) Williams, S. : Official Methods of Analysis of the Association of Official Analytical Chemists (Association of Official Analytical Chemists, Arlington), p. 176, 220 (1984)

8 ) Ando, T., Terayama, H., Nishizawa, K. and YAMAKAWA, T. : Methods of Study on Biochemistry, I (Asakura Syoten, Tokyo), p. 255 (1974)

9 ) Williams, S. : Official Methods of Analysis of the Association of Official Analytical Chemists (Association of Official Analytical Chemists, Arlington), p.224 (1984)

10) Folin, O. and DenIS, W.: A colorimetric method for the determination of phenols (and phenol 
derivatives) in urine, J. Biol. Chem., 22, 305 (1915)

11) Yanagida, F. : Handbook of Experiments in Zymurgy and Food Science (Shokuhin Kenkyu-sha, Tokyo), p. 198 (1984)

12) Harrigan, W. F. : Laboratory Methods in Food Microbiology (Academic Press, San Diego), p. 53 (1998)

13) Brewing Society of Japan : Constituents in Fermented Foods (Brewing Society of Japan, Tokyo), p.291 (1999)

14) Mura, K., Koizumi, Y., Tachi, H. and Uchimura, T. : Floras of yeasts and molds in Chinese starter, “Murcha” from Nepal, J. Brew. Soc. Japan, 91, 895 (1996)

15) Koizumi, Y., Mura, K. and Uchimura, T. : Floras of lactic acid bacteria in Chinese starter, “Murcha” from Nepal, J. Brew. Soc. Japan, 91, 901 (1996)

16) Tanimura, W., Sanchez, P. C. and Kozaki, M. : The fermented food in the Philippines. (Part 1) Tapuy (Rice wine), J. Agric. Sci., Tokyo Nogyo Daigaku, 22, 118 (1977)

17) Nishiyama, R., Sanchez, P. C. and Kozaki, M. : Inhibitory function of mangrove bark toward cell growth of microorganisms, Hakkokogaku Kaishi, 56, 712 (1978)

\section{バシ発酵における樹皮類添加の微生物の生育 ならびにバシ成分への影響}

村 清司 ${ }^{* 1} \cdot$ SANCHEZ Priscilla C. ${ }^{* 2}$. 谷村和八郎*1

* 1 東京農業大学応用生物科学部

（テ156-8502東京都世田谷区桜丘 1-1-1）

* 2 Institute of Food Science and Technology, University of the Philippines at Los Baños

(College, Laguna 4031, Philippines)

フィリピンではバシ（甘蔗酒）の発酵の際に樹皮類が 添加されることから, 発酵過程における樹皮類添加の微 生物の生育ならびにバシ成分への影響について検討した。 酵母の生育に対しては樹皮類添加の影響はほとんどみら れず，発酵後のアルコール生成量に影響はみられなかっ た。しかし，乳酸菌は樹皮類の添加により完全に生育を 抑制され，バシの発酵では樹皮類の添加によって酸敗の 原因となる乳酸菌の生育が抑えられることが確認された。 また，樹皮類を添加することによりそれらのポリフェノ ール成分が溶出して渋味を呈し，原料糖の甘味が緩和さ れて飲みやすい味となったことから, バシの製造では渋 味の付与も樹皮類添加の意義の一つであると考えられた。

(平成13年 8 月 31 日受付, 平成15年 1 月 27 日受理) 